\title{
EKSPRESI PROGESTERONE RECEPTOR (PR) PADA BENIGN, ATYPICAL DAN ANAPLASTIC MENINGIOMA
}

\author{
Jeni Poniman ${ }^{1}$, Muhammad Husni Cangara ${ }^{2}$, Cahyono Kaelan ${ }^{3}$, Gunawan Arsyadi $^{4}$, Mahmud $^{2}$ \\ Ghaznawie ${ }^{5}$, Dasril Daud 6 \\ ${ }^{1}$ Departemen Patologi Anatomi, Fakultas Kedokteran, Universitas Hasanuddin, Makassar \\ (Email: jeni.poniman@gmail.com) \\ ${ }^{2}$ Departemen Patologi Anatomi, Fakultas Kedokteran, Universitas Hasanuddin, Makassar \\ (Email: drhusni1977@yahoo.com) \\ ${ }^{3}$ Departemen Patologi Anatomi, Fakultas Kedokteran, Universitas Hasanuddin, Makassar \\ (Email: cakaelan@yahoo.com) \\ ${ }^{4}$ Departemen Patologi Anatomi, Fakultas Kedokteran, Universitas Hasanuddin, Makassar \\ (Email: gunawanarsyadi@gmail.com) \\ ${ }^{5}$ Fakultas Kedokteran, Universitas Muhammadiyah, Makassar \\ (Email: ghaznawie@gmail.com) \\ ${ }^{6}$ Departemen Ilmu Kesehatan Anak, Fakultas Kedokteran, Universitas Hasanuddin, Makassar
}

\begin{abstract}
ABSTRAK
Latar belakang: Meningioma adalah tumor otak yang paling sering pada orang dewasa dimana terapi dan followup ditentukan berdasarkan derajat histologi. Tujuan penelitian: Penelitian ini bertujuan untuk membandingkan ekspresi Progesterone Receptor (PR) pada 3 kelompok meningioma yaitu benign, atypical dan anaplastic meningioma. Metode: Penelitian ini merupakan observasi analitik dengan desain cross sectional. Sampel penelitian sebanyak 30 sampel blok parafin dengan diagnose meningioma yang dikumpulkan dari laboratorium patologi anatomi di Makassar. Blok parafin akan diproses menggunakan pewarnaan imunohistokimia antibody PR. Hasil penelitian: Ekspresi PR positif pada benign dan atypical meningioma yaitu sebanyak 15 dan 10 sampel. Ekspresi PR negatif pada anaplastic meningioma yaitu sebanyak 5 sampel. Ekspresi PR pada benign, atypical dan anaplastic meningioma masing-masing memiliki nilai $\mathrm{p}<0.05(\mathrm{p}=0.000)$. Kesimpulan: Hasil penelitian menunjukkan perbedaan ekspresi PR pada masing-masing kelompok meningioma yaitu benign, atypical dan anaplastic meningioma.
\end{abstract}

Kata Kunci: progesterone receptor, PR, meningioma, derajat histologi

Background: Meningiomas are the most common brain tumors in adults which treatment and follow-up depend on the histologic grade. Aim: This research aim is to assess the difference of Progesterone Receptor (PR) expression in 3-grade groups of meningioma which are benign, atypical and anaplastic meningioma. Method: It is analytic observational research with a cross-sectional design. The research samples were 30 paraffin block samples with meningioma diagnoses collected from the anatomical pathology laboratory in Makassar. Paraffin blocks will be processed using PR antibody with immunohistochemical staining. Result: PR immunostaining positive in benign and atypical meningioma of 15 and 10 samples. PR immunostaining negative in anaplastic meningioma of 5 samples. PR expressions in benign, atypical and anaplastic meningiomas each had a p-value less than $0.05(\mathrm{p}=0.000)$. Conclusion: The results of the study showed differences in PR expression in each meningioma grade group; benign, atypical and anaplastic meningioma.

Key Words: progesterone receptor, meningioma, histologic grade

\section{Pendahuluan}

Meningioma adalah neoplasma yang berasal dari sel meningothelial pada lapisan arachnoid, bertumbuh lambat dan umumnya bersifat jinak.(1) Oleh karena itu, pendekatan terapi pada kebanyakan pasien meningioma adalah "watch and wait", khususnya yang asimptomatik. Pada pasien yang simptomatik, dibutuhkan terapi definitif, yaitu operasi yang merupakan terapi standar dan radioterapi pada 
pasien yang beresiko tinggi untuk dilakukan operasi, pada pasien dengan reseksi subtotal atau pada pasien dengan high grade meningioma.(2) Penentuan derajat meningioma yang tepat dengan menggunakan kriteria WHO tahun 2016 penting dalam memilih terapi dan monitoring yang tepat pada setiap pasien. Namun terdapat beberapa kasus dimana tidak dapat memenuhi seluruh kriteria untuk suatu derajat histologi, sehingga diperlukan pemeriksaan tambahan untuk membantu menetukan derajat meningioma.

Progesterone merupakan regulator esensial fungsi reproduksi perempuan di uterus, ovarium, kelenjar mammae dan otak, dan juga berperan penting di jaringan non reproduksi seperti sistem cardiovascular, tulang dan sistem saraf pusat.(3) Derajat ekspresi PR cukup bervariasi yang dilaporkan pada meningioma, namun umumnya ekspresinya berbanding terbalik dengan derajat histologi. Dalam hal ini benign meningioma memiliki ekspresi positif,(4-7) sedangkan atypical dan anaplastic memiliki ekspresi negatif atau hanya menunjukkan ekspresi positif fokal.(2) Berdasarkan hal ini dilakukan penelitian untuk membandingkan ekspresi PR pada benign, atypical dan anaplastic meningioma.

\section{Metode}

Penelitian ini merupakan penelitian observasi analitik dengan menggunakan desain cross sectional. Populasi penelitian ini adalah jaringan tumor susunan saraf pusat yang dikirim ke laboratorium Patologi Anatomi RSUP DR. Wahidin Sudirohusodo dan Sentra Diagnostik Patologia Makassar yang didiagnosa sebagai benign, atypical dan anaplastic meningioma dengan pewarnaan Hematoxylin-Eosin (HE). Blok parafin yang dikumpulkan sebanyak 30 sampel dengan diagnosa benign, atypical dan anaplastic meningioma. Blok ini dipotong dengan ketebalan masing-masing 3 dan 5 mikron, kemudian diproses dengan pewarnaan rutin $\mathrm{HE}$ dan pewarnaan imunohistokimia menggunakan antibodi PR. Sampel yang sudah selesai diproses akan diperiksa di bawah mikroskop untuk ditentukan diagnosa histopatologi (derajat histologi) dan ekspresi PR.

Ekspresi PR adalah deteksi protein PR pada inti sel melalui pewarnaan imunohistokimia menggunakan mikroskop oleh 2 orang ahli patologi dengan metode double blind. Ekspresi dihitung menggunakan analisa semikuantitatif berdasarkan staining intensity yaitu skor inti sel tumor yang terwarnai. Ekspresi negatif jika tidak 
terwarnai atau terwarnai pada $<10 \%$ inti sel tumor, dan ekspresi positif jika terwarnai pada $\geq 10 \%$ inti sel tumor.

Data hasil ekspresi pada 30 sampel diolah dengan menggunakan program

\section{Hasil Penelitian}

Pada penelitian ini, sebanyak 30 sampel dikumpulkan dari Laboratorium Patologi Anatomi RSUP DR. Wahidin Sudirohusodo dan Sentra Diagnostik Patologia Makassar dalam periode 2012 hingga 2018 yang didiagnosis sebagai

Dari tabel 1, diperoleh data bahwa dari 30 sampel penelitian ini jumlah laki-laki dan perempuan masing-masing adalah $13(43.4 \%)$ dan $17(56.7 \%)$ sampel dengan diagnosa benign, atypical dan anaplastic meningioma masing-masing adalah 15 (50.0\%), 10

Dari tabel 2, diperoleh data bahwa umur sampel pada penelitian ini adalah

Dari tabel 3, diperoleh data bahwa ekspresi PR pada seluruh sampel dengan diagnosa benign dan atypical meningioma adalah masing-masing positif (100\%), sedangkan ekspresi PR pada seluruh sampel dengan diagnosa anaplastic meningioma adalah negatif (100\%). Data ini kemudian diuji

\section{Pembahasan}

Pada penelitian ini diperoleh data dengan karakteristik jenis kelamin
SPSS (Statistical Package for Social Sciences) versi 17.0. Perbandingan ekspresi PR antara benign, atypical dan anaplastic meningioma dinilai dengan mengunakan uji Chi-Square.

benign, atypical dan anaplastic meningioma. Sampel dengan diagnosa benign meningioma terdiri atas 3 subtipe yaitu meningotelial, fibrous dan transisional meningioma, masingmasing sebanyak 5 sampel.

$$
(33.3 \%) \text { dan } 5 \quad(16.7 \%) \text { sampel. }
$$

Kemudian dilakukan pewarnaan imunohistokimia menggunakan antibodi PR diperoleh ekspresi PR positif dan negatif masing-masing adalah $25(83.3 \%)$ dan $5 \quad(16.7 \%)$ sampel.

antara 26 hingga 98 tahun dengan nilai mean adalah 51.93 tahun.

menggunakan uji Chi-Square untuk menilai hubungan ekspresi PR dengan derajat histologi meningioma dan diperoleh nilai $\mathrm{p}=0.000 \quad(<0.05)$ sehingga dapat disimpulkan bahwa terdapat perbedaan ekspresi PR pada benign, atypical dan anaplastic meningioma.

perempuan dan laki-laki masing-masing adalah $13(43.4 \%)$ dan $17(56.7 \%)$ sampel sedangkan karakteristik umur 
adalah antara 26 hingga 98 tahun dengan nilai mean 51 tahun. Karakteristik jenis kelamin pada sampel penelitian ini sama dengan yang dilaporkan di USA bahwa insiden meningioma lebih tinggi pada perempuan dibandingkan laki-laki. Namun karakteristik rentang umur sedikit berbeda yaitu pada penelitian ini diperoleh rentang umur dewasa muda hingga umur lanjut. Hal ini disebabkan oleh karena perbedaan populasi penelitian, dimana kelompok ras pada populasi ini berbeda dengan penelitian lain, dan dilaporkan bahwa ras dapat mempengaruhi insidens meningioma.(1)

Karakteristik data berdasarkan derajat histologi diperoleh benign, atypical dan anaplastic meningioma masing-masing adalah 15 (50.0\%), 10 (33.3\%) dan 5 (16.7\%) sampel.. Hal ini sesuai dengan sifat meningioma yang merupakan neoplasma yang bertumbuh lambat dan umumnya bersifat benign sehingga insidensnya lebih banyak dibandingkan atypical dan anaplastic meningioma.(1)

Pada atypical meningioma terjadi instabilitas kromosom yang menyebabkan penurunan let-7 yang berperan dalam perkembangan dan differensiasi sel. Penurunan let-7 menyebabkan peningkatan Polycomb
Repressive Complex (PRC2) melalui proses hipermetilasi pada sisi human Embryonic Stem Cells (hESCs) sehingga terjadi perubahan differensiasi sel.(8,9) Perubahan differensiasi ini menyebabkan hilangnya komponen normal yang ada pada sel.

Progesterone merupakan regulator esensial fungsi reproduksi dan juga berperan penting di jaringan non reproduksi seperti sistem saraf pusat.(3) Progesterone dilaporkan terekspresi pada sel meningothelial non neoplasma dalam jumlah kecil, yang kemudian meningkat ketika terjadi proliferasi sel yaitu pada meningioma dan menurun ketika terjadi perubahan differensiasi sel.(10)

\section{Ekspresi Progesterone Receptor} (PR) pada meningioma berbanding terbalik dengan derajat histologi, dimana pada benign meningioma terjadi peningkatan ekspresi PR sebanyak 5090\% sehingga menunjukkan ekspresi PR positif sedangkan pada atypical dan anaplastic terjasi penurunan ekspresi PR masing-masing sebanyak $60-80 \%$ dan 80-90\% sehingga menunjukkan ekspresi PR fokal hingga negatif.(11) Hampir seluruh anaplastic meningioma yang dilaporkan menunjukkan ekspresi PR negatif.(1)

Pada penelitian ini diperoleh data ekspresi PR positif pada seluruh sampel 
dengan diagnosa benign (100\%) dan atypical (100\%) sedangkan negatif pada seluruh sampel dengan diagnosa anaplastic meningioma (100\%). Kemudian data ini dianalisa dengan menggunakan uji Chi-Square dan diperoleh hasil bahwa terdapat perbedaan ekspresi PR pada benign, atypical dan anaplastic meningioma.

Perbedaan ekspresi PR yang diperoleh dari hasil penelitian ini menunjukkan bahwa PR dapat digunakan dalam membantu menentukan derajat histologi meningioma. Penentuan derajat histologi terutama dapat dibantu dalam membedakan benign dan atypical meningioma dengan anaplastic meningioma.

Hal ini sejalan dengan penelitian yang dilakukan oleh Roser et al., Wolfsberger et al., Shayanfar, Mashayekh and Mohammadpour, Mukherjee et al., Ikeri, Anunobi and Bankole dimana dilaporkan bahwa ekspresi PR postitif pada benign dan atypical, dan ekspresi PR negatif pada anaplastic meningioma. $(4-6,10,12)$

Roser et al., Shayanfar, Mashayekh and Mohammadpour, Mukherjee et al., Ikeri, Anunobi and Bankole merekomendasikan PR untuk digunakan dalam pemeriksaan rutin untuk membantu menilai sifat dari meningioma yaitu membedakan derajat diferensiasi dengan nilai yang berbanding terbalik dengan derajat histologi, walaupun terdapat nilai yang overlap antara benign dana atypical meningioma yaitu keduanya memiliki ekspresi PR positif.(5,6,10,12)

Roser et al. menambahkan bahwa sebaiknya PR dikombinasikan dengan marker lain untuk selain membantu menilai sifat meningioma, juga dapat memprediksi rekurensi dan menentukan strategi follow-up yang lebih efektif.(12)

\section{Kesimpulan dan Saran}

Hasil penelitian ini menunjukkan perbedaan ekspresi Progesterone Receptor (PR) pada benign, atypical dan anaplastic meningioma, yaitu positif pada benign dan atypical meningioma, dan negatif pada anaplastic meningioma. Berdasarkan hasil ini, PR dapat digunakan sebagai marker tambahan untuk membantu membedakan benign dan atypical meningioma dengan anaplastic meningioma terutama pada kasus dimana sulit menentukan derajat histologi berdasarkan WHO tahun 2016 melalui perwarnaan rutin Hematoxylin$\operatorname{Eosin}(\mathrm{HE})$. 


\section{Daftar Pustaka}

1. Perry A, Louis DN, Budka H, von Deimling A, Sahm F, Rushing EJ, et al. Meningioma. In: Louis DN, Ohgaki H, Wiestler OD, Cavenee WK, editors. WHO Classification of Tumours of the Central Nervous System. Revised4th ed. Lyon: International Agency for Research on Cancer (IARC); 2016. p. 232-7.

2. Perry A. Meningiomas. In: Perry A, Brat DJ, editors. Practical Surgical Neuropathology: A Diagnostic Approach. 1st ed. Philadelphia: Churchill Livingstone an affiliate of Elsevier Inc.; 2010. p. 185-217.

3. Scarpin KM, Graham JD, Mote PA, Clarke CL. Progesterone Action in Human Tissues: Regulation by Progesterone Receptor ( PR ) Isoform Expression, Nuclear Positioning and Coregulator Expression. Open Access J Nucl Recept Signal Atlas. 2009;7:113.

4. Wolfsberger S, Doostkam S, Boecher-Schwarz, Hans-Gerd Roessler K, van Trotsenburg M, Hainfellner JA, Knosp E. Progesterone-Receptor Index in Meningiomas : Correlation with Clinico-Pathological Parameters and Review of the Literature. Neurosurg Rev. 2004;27:238-45.

5. Shayanfar N, Mashayekh $\mathrm{M}$,
Mohammadpour M. Expression of Progestrone Receptor and Proliferative Marker Ki 67 in Various Grades of Meningioma. Acta Med Iran. 2010;48(3):142-7.

6. Mukherjee S, Nath Ghosh S, Chatterjee U, Chatterjee S. Detection of Progesterone Receptor and the Correlation with Ki-67 Labeling Index in Meningiomas. Neurol India. 2011;59(6):817-22.

7. Mukhopadhyay M, Das C, Kumari M, Sen A, Mukhopadhyay B, Mukhopadhyay B. Spectrum of Meningioma with Special Reference to Prognostic Utility of ER, PR and Ki67 Expression. J Lab Physicians. 2017;9(4):308-13.

8. Rosa A, Brivanlou AH. Regulatory Non-Coding RNAs in Pluripotent Stem Cells. Int J Mol Sci. 2013;14:14346-73.

9. Harmanc1 AS, Youngblood MW, Clark VE, Coskun S, Henegariu O, Duran D, et al. Integrated Genomic Analyses of De Novo Pathways underlying Atypical Meningiomas. Nat Commun [Internet]. 2017;8(14433):1-14. Available from: www.nature.com/naturecommunicati ons

10. Ikeri NZ, Anunobi CC, Bankole OB. Progesterone Receptor Expression and $\mathrm{Ki}$ - 67 Labelling Index of 
Meningiomas in the Lagos University Teaching Hospital. Niger Postgrad Med J [Internet]. 2018;25:17-20. Available from: www.npmj.org

11. Perry A. Meningioma. In: Perry A, Brat DJ, editors. Practical Surgical Neuropathology: A Diagnostic Approach. 2nd ed. Philadelphia: Elsevier; 2018. p. 259-98.

12. Roser F, Nakamura M, Bellinzona M, Rosahl SK, Ostertag H, Samii M. The Prognostic Value of Progesterone Receptor Status in Meningiomas. J Clin Pathol. 2004;57:1033-8. 


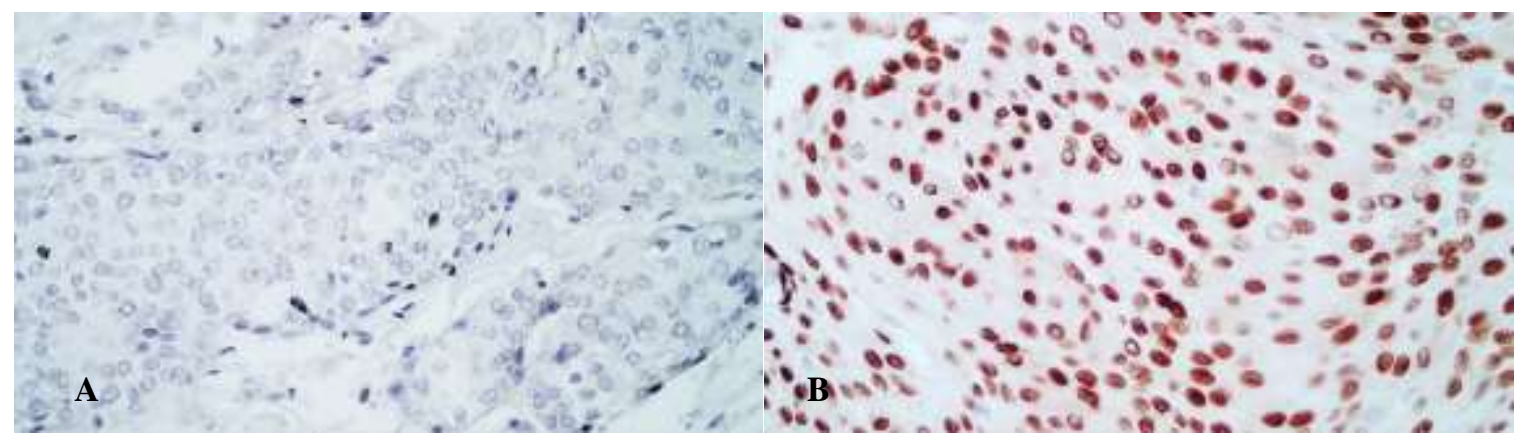

Gambar 3.1 (a) Ekspresi Progesterone Receptor (PR) Negatif. (b) Ekspresi PR Positif. (Objektif 400X)

Tabel 3.1 Karakteristik Sampel berdasarkan Jenis Kelamin, Derajat Histologi dan Ekspresi PR

\begin{tabular}{llcc}
\hline & Karakteristik & $\mathrm{n}$ & $\%$ \\
\hline \multirow{2}{*}{ Jenis Kelamin } & Laki-Laki & 13 & 43.4 \\
& Perempuan & 17 & 56.7 \\
\hline \multirow{2}{*}{ Meningioma } & Benign & 15 & 50.0 \\
& Atypical & 10 & 33.3 \\
& Anaplastic & 5 & 16.7 \\
\hline \multirow{2}{*}{ Ekspresi PR } & Positif & 25 & 83.3 \\
& Negatif & 5 & 16.7 \\
\hline
\end{tabular}

$\mathrm{PR}=$ Progesterone Receptor.

Tabel 3.2 Karakteristik Umur

\begin{tabular}{lccc}
\hline & Mean & Minimum & Maximum \\
\hline Umur (Tahun) & 51.93 & 26 & 98 \\
\hline
\end{tabular}

Tabel 3.3 Karakteristik Ekspresi PR berdasarkan Derajat Histologi Meningioma

\begin{tabular}{lcccc}
\hline \multirow{2}{*}{ Ekspresi PR } & \multicolumn{3}{c}{ Meningioma } & \multirow{2}{*}{ Total (\%) } \\
\cline { 2 - 4 } Positif & Benign (\%) & Atypical $(\%)$ & Anaplastic (\%) & $25(83.3)$ \\
Negatif & $15(100)$ & $10(100)$ & $0(0)$ & $5(16.7)$ \\
\hline Total $(\%)$ & $0(0)$ & $0(0)$ & $5(100)$ & $30(100)$ \\
\hline
\end{tabular}

Uji Chi-Square; $\mathrm{p}=0.000(<0.05)$. $\mathrm{PR}=$ Progesterone Receptor . 